\title{
Underground water affects sexual behavior and gene expression of hormones related to reproduction in blue gourami males
}

\author{
Gad Degani $^{1,2}$, Gal Levy ${ }^{1,2}$ \\ ${ }^{1}$ School of Science and Technology, Tel-Hai Academic College, Upper Galilee, Israel \\ ${ }^{2}$ MIGAL, Galilee Technology Center, Kiryat Shmona, Israel \\ Email: gad@migal.org.il
}

Received 18 October 2012; revised 19 November 2012; accepted 26 November 2012

\begin{abstract}
This study examined the effect of underground water on reproduction- and growth-related hormones in blue gourami males under non-reproductive and reproductive conditions. An increase in the percentage of males building nests under the highest percentage of underground water were compared to fish that maintained a lower percentage of underground water in the first two days. The \% Gonado-somatic index (GSI) of males building nests was higher than nonreproductively active males in water containing the lowest concentration of underground water. In nonreproductively active males, brain gonadotropin releasing hormone 1 (GnRH1) and pituitary $\beta$ subunit of gonadotropins (GtHs) and prolactin (PRL) mRNA levels were significantly higher in males maintained in underground water. In reproductively active males, mRNA levels of brain GnRH1, gonadotropin releasing hormone 3 (GnRH3) and pituitary PRL mRNA levels were significantly higher than males maintained in underground water. Thus, it is suggested that underground water with high salinity and conductivity levels affects the gene expression of reproduction-related hormones; in reproductively active males, it shortened the duration of nest-building by blue gourami males.
\end{abstract}

Keywords: Growth; Reproduction; Salinity; Teleosts

\section{INTRODUCTION}

The environmental effect on hormones that regulate reproduction and growth in fish has been studied extensively, focusing particularly on photoperiod $[1,2]$, temperature [3-10], water quality [11], salinity $[12,13]$ and $\operatorname{diet}[14]$.

All gourami fish belong to the Anabantoidei suborder and are commonly known as labyrinth fish. These fish are characterized primarily by an accessory breathing organ called the labyrinth organ. The labyrinth organ is located next to the gill cavities and is made up of folded membranes mounted on a bony frame able to uptake atmospheric oxygen and adapt the fish to low quality water [15]. Anabantidae, which contains 16 genera and about 50 species, is distributed throughout most of southern Asia, India and Central Africa [15], and lives in habitats with various water sources and different soluble components $[6,16]$. The habitats are affected by seasonal rains and might affect the standing-water where the fish breed. The conditions of this fish in natural habitats are not described in detail, however, intensive study has been carried out on the adaptation to growth and reproduction in artificial conditions [15]. In tropical regions, the two main reproductive cues are temperature and day length with little seasonal variation. Nest-building occurs and eggs are laid in a temperature range of $23^{\circ} \mathrm{C}-29^{\circ} \mathrm{C}$ [16]. Degani states that the reduction of light due to dense plant population had a positive effect on nest-building. In light [6] conditions, the females generally lay their eggs by the second day after being placed in the spawning container, after which the number of nests built declines. In dark conditions, spawning begins more slowly and the decrease in spawning is slower. More spawns in total were achieved in conditions of darkness versus light. Moreover, they are known to be very tolerant to wide ranges of environmental conditions, including varying $\mathrm{pH}(6.0-8.8)$, temperature $\left(3^{\circ} \mathrm{C}-21^{\circ} \mathrm{C}\right)$ and dissolved oxygen levels [17]. The blue gourami has been studied extensively as the model of endocrine regulation on reproduction and growth since it is multi-spawning and male-dependent, with asynchronic ovary development $[15,18]$. Thus, each stage of its gonadal development can be controlled and examined separately in the laboratory [19-21].

Several studies have shown an association between brain, pituitary, gonads, hormones and reproduction and 
growth in the blue gourami male. The pituitary gene expression of follicle-stimulating hormone $(\beta \mathrm{FSH})$, luteinizing hormone $(\beta \mathrm{LH})[21]$, prolactin (PRL) [22] and growth hormone $(\mathrm{GH})$ in males [23], and the pattern of sex steroid secretion during gonadal development in blue gourami males have been reported previously $[21,24]$. $\beta$ FSH mRNA levels increase in mature non-reproductively active fish; $\beta$ LH mRNA levels were related to sexual behavior [21]. The highest levels of blue gourami GH mRNA were found in pituitaries of non-reproductively active males, suggesting that GH may play a role in the gonadal cycle and sexual behavior of the blue gourami [23,25]. Degani et al. [22] suggested that PRL plays a possible role in the endocrine control of gonadal development in fish, in addition to its role in reproductive behavior. An association between brain peptide gene expression and gonadal cycle was also studied in blue gourami males. Three forms of gonadotropin-releasing hormone $(\mathrm{GnRH})$ exist in blue gourami males ( $\mathrm{GnRH} 1$, GnRH2 GnRH3). GnRH1 gene expression was higher in mature non-reproductively active males [26]. No changes in GnRH2 gene expression was detected in blue gourami males under non-reproductive and reproductive conditions [26]. Gonadotropin-releasing hormone3 (GnRH3) induces LH release from pituitary cells and stimulates final oocyte maturation (FOM) in blue gourami females [27]. Levy et al. (2009) demonstrated that higher GnRH3 mRNA levels were detected in the brain of mature (during spermatogenesis) and reproductively active males (during nest-building) than in juvenile males [28]. Pituitary adenylate cyclase-activating polypeptide (PACAP) gene expression is related to sexual behavior, and high levels of PACAP-related peptide (PRP) gene expression were detected in non-reproductive males. The potential role of these peptides in reproduction and growth is also supported by their regulation on $\mathrm{GH}$ and gonadotropin gene expression $[29,30]$.

To date, the effect of changes in water conditions such as salinity and conductivity on hormones involved in growth and reproduction is not fully understood in Anabantoidei fish. Molecular analysis of the main hypothalamic peptides regulating growth and reproduction in fish maintained in underground water differ in their chemical characterizations, could provide an insight into their physiological role. Therefore, the aim of this study was to examine the effect of underground water on gene expression ( $\beta \mathrm{FSH}, \beta \mathrm{LH}, \mathrm{GH}, \mathrm{PRL}, \mathrm{GnRH} 1$ and $\mathrm{GnRH} 3)$ in blue gourami males under reproductive and non-reproductive conditions.

\section{MATERIAL AND METHODS}

\subsection{Fish and Experimental Design}

Blue gourami fish (Trichogaster trichopterus, Percifor- mes, Osphronemidae), which were maintained and bred at MIGAL laboratories in northern Israel, were used in this study. The fish were held in containers $(2 \times 2 \times 0.5$ $\mathrm{m})$ at a temperature of $27^{\circ} \mathrm{C}$, under a light regime of $12 \mathrm{~h}$ light:12 h darkness (Jackson et al., 1994) until the beginning of the experiments, and were fed an artificial diet (45\% protein, $7 \%$ fat) supplemented with live food ( $\mathrm{Ar}$ temia salina). All research involving the fish was approved by the committee in MIGAL dealing with animals and conforms to NIH guidelines.

\subsection{Experimental Design}

Experiment 1: the effect of different underground water conditions with different salinity and conductivity levels on genes encoding for growth and reproduction hormones in non-reproductively active males.

Three separate aquariums, each containing underground water $(0 \%, 50 \%, 100 \%)$ with different salinity and conductivity levels (Table 1) were populated with 10 non-reproductively active adult blue gourami males (with an average weight of $7.61 \pm 0.28 \mathrm{~g}$ ). After an acclimation period of four days, the experiment was carried out for four days.

Experiment 2: the effect of the different underground water conditions with different salinity and conductivity levels on genes encoding for growth and reproduction hormones in reproductively active males.

Reproductively active blue gourami males with an average weight of $10.45 \pm 2.96 \mathrm{~g}$ were maintained in groups of five fish per container in three separate aquariums, each containing underground water $(0 \%, 50 \%$, $100 \%$ ) for a four-day acclimation period. The fish were then separated so that each aquarium contained only one male for three days. Vegetation (Elodea) was added to each aquariums, and a mature female was added to each aquarium after two days. This experiment was repeated 2 3 times.

In all the experiments, the brains and pituitaries were collected and somatic and gonadal weights were recorded for gonadosomatic index (GSI) calculations. The

Table 1. Water quality in different $\%$ of underground water.

\begin{tabular}{ccccccc}
\hline $\begin{array}{c}\text { \% of underground } \\
\text { water }\end{array}$ & \multicolumn{2}{c}{$0 \%$} & \multicolumn{2}{c}{$50 \%$} & \multicolumn{2}{c}{$100 \%$} \\
\hline & mean & SD & mean & SD & mean & SD \\
\hline $\begin{array}{c}\text { Dissolved Oxygen } \\
(\mathrm{mg} / \mathrm{L})\end{array}$ & 6.91 & 0.34 & 7.25 & 0.36 & 6.56 & 0.28 \\
Conductivity (uS) & 346.27 & 27.48 & 954.89 & 29.42 & 1908 & 43.47 \\
Temperatures $\left({ }^{\circ} \mathrm{C}\right)$ & 27.05 & 0.94 & 27.14 & 0.84 & 27.30 & 0.94 \\
Salinity (ppm) & 0.2 & 0.02 & 0.56 & 0.05 & 1.11 & 0.06 \\
Ammonia (ppm) & 0.6 & 0 & 0.6 & 0 & 0.6 & 0 \\
$\mathrm{NO}_{2}(\mathrm{ppm})$ & 0.74 & 0.15 & 0.74 & 0.16 & 0.75 & 0.15 \\
\hline
\end{tabular}


pituitaries were removed from the fish to measure $\beta \mathrm{FSH}$ and $\beta \mathrm{LH}$ [31], GH [23] and PRL [22], and all the brains were sampled for GnRH1 and GnRH3 transcription measurements [26,28] In addition, gonads were examined histologically to determine the reproductive stage.

\subsection{Histological Analysis}

Gonadal samples were fixed in Bouin and subsequently processed for light microscopy. Paraffin sections of $6 \mu \mathrm{m}$ were stained with hematoxylin and eosin, as previously described [18]. Mature males displayed full spermatogenesis and a high concentration of spermatozoa in the middle of the testes lobuli [21]. The reproductive stages in males were mature non-reproductively active, which were kept in groups, and mature reproductively active males, which were maintained under reproductive conditions and built nests [32].

\subsection{RNA Extraction and cDNA Synthesis}

Total RNA was extracted from freshly excised brains and pituitaries of blue gouramis using Trizol reagent (Invitrogen, Carlsbad, CA), according to the manufacturer's recommendations. RNA samples were incubated with RNase-free deoxyribonuclease-I (Roche Diagnostics, Mannheim, Germany) to eliminate contaminating genomic DNA. First-strand cDNA was synthesized from 0.5 to $2 \mathrm{mg}$ of the total RNA for $1 \mathrm{hr}$ at $57^{\circ} \mathrm{C}$ followed by 10 $\min$ at $75^{\circ} \mathrm{C}$ with the Reverse-IT First-Strand Synthesis Kit (ABgene, Surrey, UK).

\subsection{Real-Time PCR}

The mRNA levels of GnRH1, GnRH3, GH, bLH, bFSH and prolactin in the gourami pituitary were determined.
The relative abundance of mRNA was normalized with an endogenous reference gene, the $18 \mathrm{~S}$ subunit of rRNA (18S rRNA), using the comparative threshold cycle (CT) method [33]. The formula used was $2^{\Delta \mathrm{CT}}$, where $\Delta \mathrm{CT}$ corresponds to the difference between the CT measured for each target hormone (GnRH1, GnRH3, GH, bLH, $\mathrm{bFSH}$, or prolactin) and the CT determined for $18 \mathrm{~S}$ rRNA. To validate this method, serial dilutions were prepared from a brain cDNA sample and the efficiencies of each gene were calculated according to the method of Muller et al. [34]. Linear regressions of the plots showed R2 values of 0.99 . Gene-specific primers for the realtime PCR were designed using Primer3 Tool

(http://frodo.wi.mit.edu/primer3/). Table 2 summarizes the primers used in the real-time PCR. In each PCR mixture, Syber Green Master Mix (ABgene) was added and amplification was carried out in a RotorGene 3000 Sequence Detection System (Corbett Research, Sydney, Australia) under the following conditions: for GnRH1$95^{\circ} \mathrm{C}$ for $15 \mathrm{~min}$, followed by 40 cycles of $95^{\circ} \mathrm{C}$ for 10 sec, $52^{\circ} \mathrm{C}$ for $20 \mathrm{sec}, 72^{\circ} \mathrm{C}$ for $20 \mathrm{sec}$ and $82^{\circ} \mathrm{C}$ for $15 \mathrm{sec}$; for $\mathrm{GnRH} 3$ - initial denaturation and enzyme activation at $95^{\circ} \mathrm{C}$ for $15 \mathrm{~min}$, followed by 40 cycles of $95^{\circ} \mathrm{C}$ for 10 $\mathrm{sec}, 54^{\circ} \mathrm{C}$ for $20 \mathrm{sec}, 72^{\circ} \mathrm{C}$ for $20 \mathrm{sec}$ and $83^{\circ} \mathrm{C}$ for $10 \mathrm{sec}$; for $\beta \mathrm{LH}-95^{\circ} \mathrm{C}$ for $15 \mathrm{~min}$, followed by 40 cycles of $95^{\circ} \mathrm{C}$ for $10 \mathrm{sec}, 60^{\circ} \mathrm{C}$ for $15 \mathrm{sec}$ and $72^{\circ} \mathrm{C}$ for $20 \mathrm{sec}$; for $\beta \mathrm{FSH}-95^{\circ} \mathrm{C}$ for $15 \mathrm{~min}$, followed by 40 cycles of $95^{\circ} \mathrm{C}$ for $10 \mathrm{sec}, 57^{\circ} \mathrm{C}$ for $20 \mathrm{sec}$ and $72^{\circ} \mathrm{C}$ for $20 \mathrm{sec}$; for $\mathrm{GH}$ - initial denaturation at $95^{\circ} \mathrm{C}$ for $15 \mathrm{~min}$, followed by 40 cycles of $95^{\circ} \mathrm{C}$ for $10 \mathrm{sec}, 64^{\circ} \mathrm{C}$ for $20 \mathrm{sec}, 72^{\circ} \mathrm{C}$ for $20 \mathrm{sec}$ and $83^{\circ} \mathrm{C}$ for $15 \mathrm{sec}$; for prolactin $-95^{\circ} \mathrm{C}$ for 15 min, followed by 40 cycles of $95^{\circ} \mathrm{C}$ for $15 \mathrm{sec}, 54^{\circ} \mathrm{C}$ for $25 \mathrm{sec}$ and $72^{\circ} \mathrm{C}$ for $20 \mathrm{sec}$; and for $18 \mathrm{~S}$ rRNA $-95^{\circ} \mathrm{C}$ for $10 \mathrm{~min}$, followed by 40 cycles of $95^{\circ} \mathrm{C}$ for $15 \mathrm{sec}, 64^{\circ} \mathrm{C}$

Table 2. Nucleotide sequences of primers.

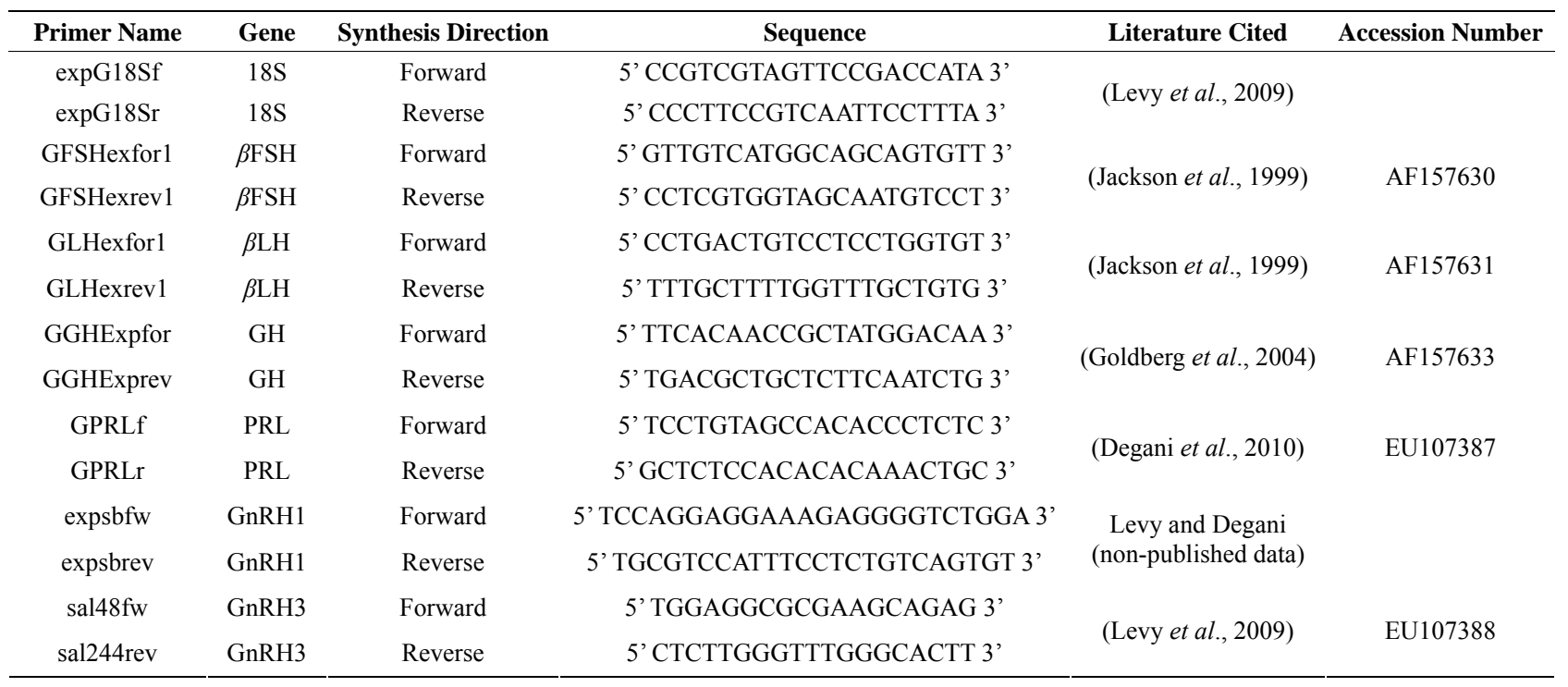


for $20 \mathrm{sec}$ and $72^{\circ} \mathrm{C}$ for $20 \mathrm{~s}$. Amplifications of each target gene and reference gene cDNA were performed simultaneously in separate tubes in duplicate, and results were analyzed with QGene software (BioTechniques Software Library at: www.BioTechniques.com). Dissociation-curve analysis was run after each real-time experiment to ensure that there was only one product. To control for false positives, a non-template negative control was run for each primer pair.

\subsection{Statistical Analysis}

Data of the transcription of each gene are presented as mean \pm SEM. The significance of the differences between group means of hormone mRNA levels was determined by one-way analysis of variance (ANOVA). In order to compare between every two different underground water conditions (between $0 \%$ and $50 \%$; between $0 \%$ and $100 \%$ and between $50 \%$ and $100 \%$ ), Student's t-test data analysis was performed using the Statistical Package for the Social Sciences 17.0 software (Chicago: SPSS Inc). The comparison differences were considered to be statistically significant at $\mathrm{P}<0.05$.

\section{RESULTS}

\subsection{Effect of Underground Water on the Sexual Behavior of Males}

Males maintained in groups (10 per aquarium) in different concentration of underground water $(0 \%, 50 \%$, $100 \%$ ) having high salinity and conductivity levels did not demonstrate any sexual behavior (they did not build nests). In contrast, males that had been kept separated (one per aquarium), built nests in all three different underground water. However, there was a significant high variation in the percentage of males that build nests at a high underground water concentration $(100 \%)$ compared to fish maintained at low underground water concentrations in the first two days $(\mathrm{P}<0.05$, one-tailed Student's t-test) (Figure 1). No morphological differences could be observed among the testes of males maintained at the three different underground water conditions at all stages of spermatogenesis (spermatogonia, spermatocyte, spermatids and spermatozoa) (Figure 2). The \% GSI of males building nests was higher than non-reproductively active males in water containing the lowest underground water ( $\mathrm{P}<0.05$, one-tailed Student's t-test) (Figure 3).

\subsection{Effect of Underground Water on the Relative mRNA Levels of Brain and Pituitary Hormones of Blue Gourami Males Maintained in Groups (under Non-Reproductive Conditions)}

The mRNA levels of brain hormones (GnRH1 and

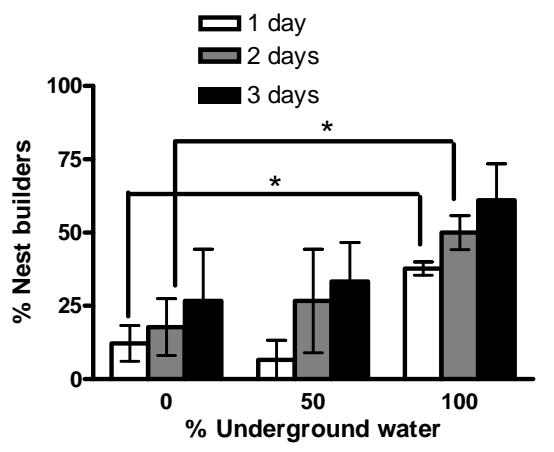

Figure 1. The percentage of males building nests at different underground water conditions $(0 \%, 50 \%$ and $100 \%)$ with high $\mathrm{NaCl}$ concentrations $(0.2 \pm 0.02 \mathrm{ppm}, 0.56 \pm 0.05$ ppm, $1.11 \pm 0.06 \mathrm{ppm}$, respectively). Asterisk above each bar of the histogram denotes a significant difference between $0 \%$ underground water condition to other underground water conditions on each day $(\mathrm{P}<0.05$, one-tailed Student's t-test).
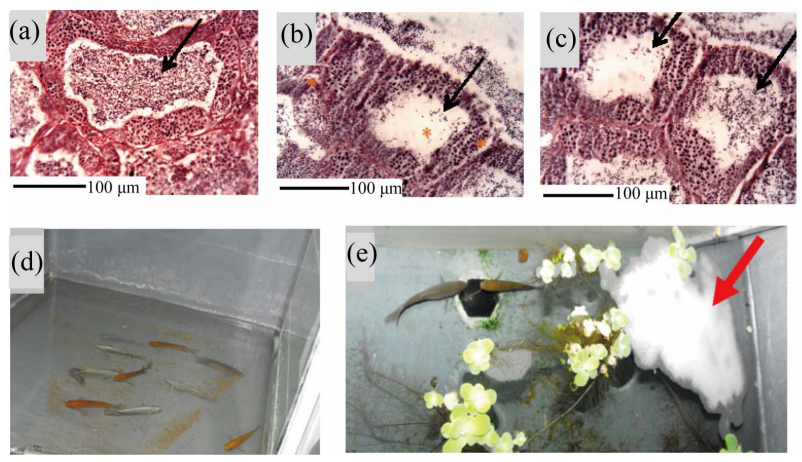

Figure 2. Histology sections of testis in on-reproductively active males (a) and reproductively active males (b) + (c). Note the high concentration of SZ in the middle of the lobule (a). Fish in non-reproductive conditions maintained in group (d) and in reproductive conditions building nests (e). Spermatogenesis stages in the gonads of mature non-reproductively active blue gourami males. The histological section shows the cellular spermatogenesis stages in the gonad of mature non-reproductively active blue gourami males (f). Cellular spermatogenesis stages are present on the periphery of the lobule: SG, spermatogonia; SC, spermatocytes; ST, spermatids; SZ, spermatozoa. Sections were stained with hematoxylin and eosin.

GnRH3) and pituitary hormones $(\beta \mathrm{LH}, \beta \mathrm{FSH}, \mathrm{GH}$ and PRL) at various underground water conditions in males under non-reproductive conditions (FNRC) are presented in Figure 4. GnRH1, $\beta \mathrm{LH}$ and $\beta \mathrm{FSH}$ mRNA levels were significantly higher at $50 \%$ and $100 \%$ underground water conditions compared to $0 \%$; PRL mRNA levels were significantly higher only in $100 \%$ underground water compared to $0 \%$. On the other hand, no significant differences were found in GnRH3 and GH mRNA levels at various percentages of underground water conditions (Figures 4(a) and (b), respectively). 


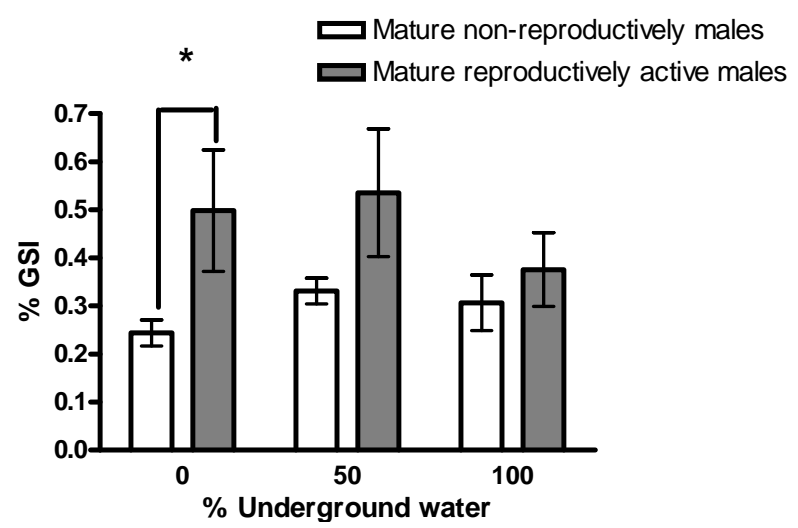

Figure 3. The gonado-somatic index (\% GSI) of fish in various underground water conditions (mean \pm SEM; $n=5-10$ ). Significant differences were found in $0 \%$ underground water $)(\mathrm{P}<$ 0.05 , Student's t-test).

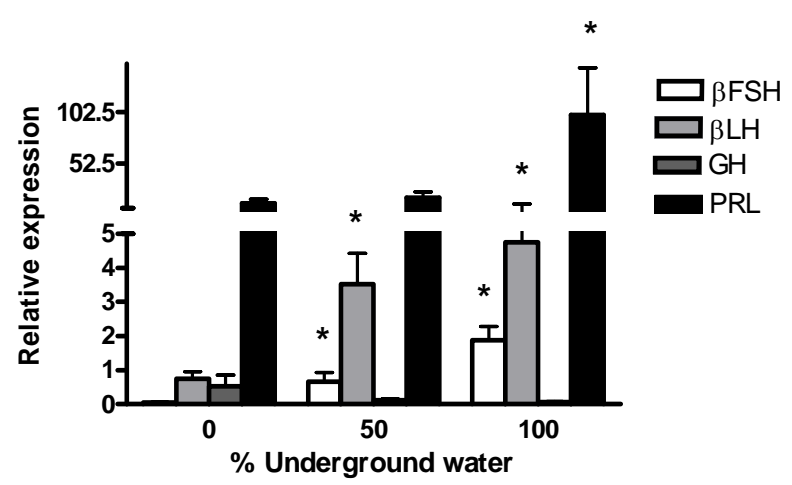

(a)

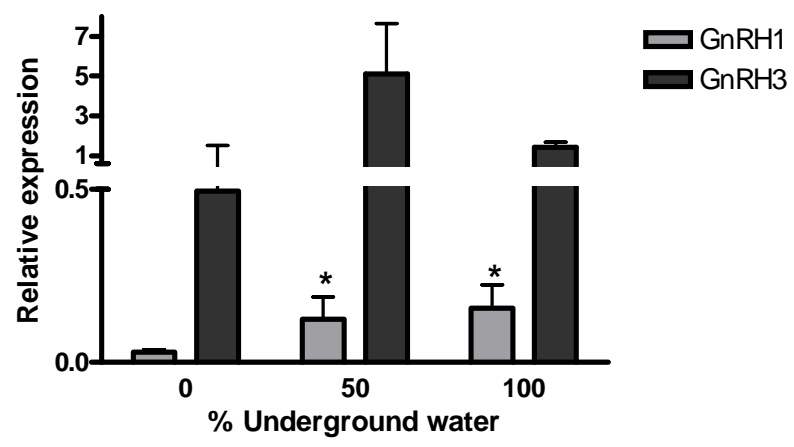

(b)

Figure 4. The effect of different underground water conditions on mRNA levels of brain and pituitary hormones in males under non-reproductive conditions. (a) $\beta \mathrm{LH}, \beta \mathrm{FSH}$ GH and PRL; (b) GnRH1 and GnRH3. Blue gourami males maintained in groups were selected randomly and kept for a four-day acclimation period. The experiment was carried out on the fish for four days, 10 fish per container $(\mathrm{n}=30)$. Total RNA from brains and pituitaries was reverse-transcribed for a quantitative real-time PCR. Each histogram represents the average of $7-10$ independent measurements (mean $\pm \mathrm{SEM}$ ). Asterisk above each histogram denotes a significant difference between mRNA levels in males at $0 \%$ to other underground conditions $(\mathrm{P}<0.05$, t-test).

\subsection{Effect of Underground Water on the Relative mRNA Levels of Brain and Pituitary Hormones of Blue Males Maintained Alone (under Reproductive Conditions)}

The mRNA levels of brain hormones (GnRH1 and GnRH3) and pituitary hormones $(\beta \mathrm{LH}, \beta \mathrm{FSH}, \mathrm{GH}$ and PRL) at various underground water conditions in males under reproductive conditions (FRC) are presented in Figure 5. GnRH1 mRNA levels were significantly higher at $50 \%$ and $100 \%$ underground water conditions compared to $0 \%$; PRL mRNA levels were significantly higher at $100 \%$ underground water compared to $0 \%$; and GnRH3 mRNA levels were significantly higher at 50\% underground water compared to $0 \%$. On the other hand, no significant differences were found in $\beta \mathrm{LH}, \beta \mathrm{FSH}$ and GH mRNA levels at various percentages of underground water conditions.

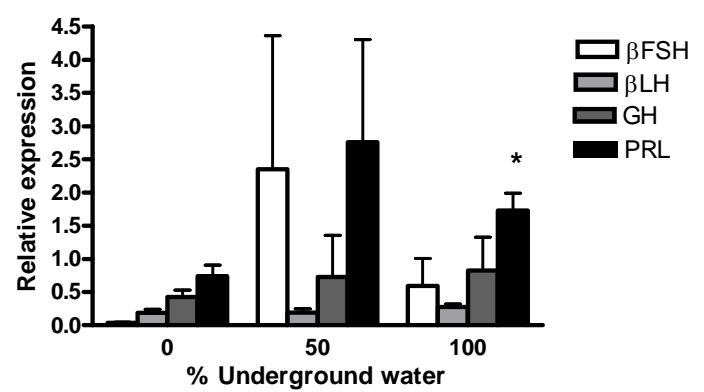

(a)

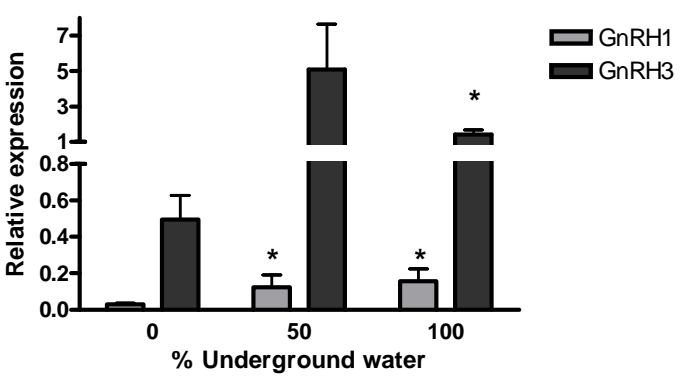

(b)

Figure 5. The effect of different underground water conditions on mRNA levels of brain and pituitary hormones in males under reproductive conditions. (a) $\beta \mathrm{LH}, \beta \mathrm{FSH}$ GH and PRL; (b) GnRH1 and GnRH3. Blue gourami males maintained with females under reproductive conditions. After the four-day acclimation period in the group, the fish were separated for three days (so that each aquarium contained only one male and a mature female was add to each aquarium after the first day). Total RNA from brains was reverse-transcribed for a quantitative real-time PCR. Each histogram represents the average of 5 - 7 independent measurements (mean \pm SEM). Asterisk above each histogram denote a significant difference between mRNA levels in males at $0 \%$ to other underground conditions $(\mathrm{P}<0.05$, Student's t-test). 


\section{DISCUSSION}

Water quality affects the growth and survival of fish as well as their metabolism [35]. It is well known that labyrinth fish, to which the blue gourami belong, adapt to low water quality having a low oxygen concentration since they possess an air-filled breathing cavity having the ability to use atmospheric oxygen. The current study demonstrates that in the blue gouramis, underground water having high salinity and conductivity levels than their normal habitat affects mRNA levels of genes encoded to the main hormones involved in growth and reproduction as well as sexual behavior. This result supports the hypothesis that water composition affects reproduction and sexual behavior through alternation in gene expression at the brain pituitary axis.

Trichogaster trichopterus is a tropical fish that exists in a habitat having a relatively constant temperature range [15]; in this habitat, these fish reproduce all year round in the $23^{\circ} \mathrm{C}-31^{\circ} \mathrm{C}$ temperature range [6]. In this habitat, water is highly affected by rain. Relatively great attention has been paid to the endocrine control of prolactin and growth hormone in the adaptation to gradual or rapid salinity changes [36-38]. In salmonid, LH and FSH response to salinity challenge was studied [39], However in freshwater fish, data about the effect of changes in water osmolarity on these hormones in are limited.

In some fish, the life history passes from freshwater to seawater to spawn, e.g. Anguilla species [40], and hormone control reproduction might be affected by $\mathrm{NaCl}$ concentration. The pituitary-gonadal axis homing chum salmon was also examined during the life cycle and migration to freshwater [39]. Although the blue gourami is not classical migratory fish, under natural conditions, it inhabits shallow sluggish or standing water, ponds, ditches, swamps and marshes having considerable aquatic vegetation. Habitats affected by seasonal rains influence the standing water where the fish breed. There is no detailed description of conditions in natural habitats; however, extensive study has been made regarding the adaptation to growth and reproduction under artificial conditions $[15,16]$. It is suggested that the salinity and conductivity of water in natural habitats, which is of low quality, changes during the rainy season, thus affecting reproduction, as was found in the current study. In this study, changes in the salinity of water affected pituitary and brain gene expression with respect to the reproductive stage.

In non-reproductively active males, GnRH1, $\beta \mathrm{LH}$, $\beta$ FSH and PRL mRNA levels were significantly higher in males maintained in underground water having a high salinity and conductivity levels. These fish exhibit a high rate of spermatogenesis, and GnRH1 and GtHs are the main regulators of this process [41], which might explain their high sensitivity to environmental changes. A previous study in our lab showed that high mRNA levels of $\mathrm{GnRH} 1, \beta \mathrm{FSH}$ and prolactin (PRL) were detected in mature non-reproductively active males compared to juveniles $[21,22,42]$. This is in agreement with the mRNAs encoding GTH subunits in the pituitaries of maturing adults, which were significantly higher than those of immature fish in chum salmon that correlated to water salinity [39]. In blue gourami, GnRH1 increased $\beta$ LH and $\beta$ FSH gene expression in pituitary dispersed cells [42]. The involvement of PRL osmoregulation was studied extensively [37], however this work supports a previous study of tilapia showing that GnRH stimulate PRL release [43].

Reproductively active males demonstrated sexual behavior in building nests and an increase in mRNA levels of GnRH1, GnRH3 and PRL; a large percentage of bubble nests was detected in fish maintained in underground water having a high salinity and conductivity levels. The correlation between GnRH1 and GnRH3 with sexual behavior and nest-building was previously reported for blue gourami and other fish $[44,45]$. Thus, it is suggested that in non-reproductively active males, an increase in water salinity and conductivity induces GnRH1gene expression, which in turn increases GtH and PRL synthesis. Nest building behavior and parental care in such fish appear to be under the regulation of prolactin [46]. On the other hand, in mature reproductively active males, an increase in water salinity and conductivity also induces GnRH3 gene expression, which induces nest-building.

The lack of change in GH mRNA level with an increase in water salinity and conductivity supports previous findings for gourami, showing relatively constant expression levels during reproduction stages in male blue gourami that do not increase significantly with sexual behavior [21].

In summary, the above discussion concludes that changes in salinity and conductivity levels from underground water affects hormone control reproduction and is in agreement with what was found regarding the hormone most involved in the sexual behavior of blue gourami males.

\section{REFERENCES}

[1] Dodd, J.M. and Sumpter, J.P. (1982) Reproductive cycles of cyclostomes, elasmobranchs and bony fishes. In: Lamming, G.E., Ed., Marshall's Physiology of Reproduction, Churchill Living-stone, London, 1-126.

[2] Munro, A.D., Scott, A.P. and Lam, T.J. (1990) Reproductive seasonality in Teleosts: Environmental influences. CRC Press, Boca Raton.

[3] Drori, S., Michal, O.M., Levavi-Sivan, B. and Yaron, Z. (1994) Spawning induction in common carp (Cyprivtus carpio) using pituitary extract or GnRH superactive ana- 
logue combined with metoclopramide: Analysis of hormone profile, progress of oocyte maturation and dependence on temperature. Aquaculture, 119, 393-407. doi:10.1016/0044-8486(94)90303-4

[4] Yaron, Z. (1969) Correlation between spawning, water temperature and thyroid activity in Acanthobrama terraesanctae (Cyprinidae) of Lake Tiberias. General and Comperative Endocrinology, 12, 604-608. doi:10.1016/0016-6480(69)90180-4

[5] Yaron, Z., Bogomolnaya, A. and Levavi, B. (1984) A calibrated carp pituitary extract as a spawning-inducing agent. Research on Aquaculture, 8th Edition, Europe Mariculture Society, Bredene.

[6] Degani, G. (1989) The effect of temperature, light, fish size and container size on breeding of Trichogaster trichopterus. Israeli Journal of Aquaculture Bamidgeh, 41, 67-73.

[7] Holloway, A.C., Sheridan, M.A., Van der Kraak, G. and Leatherland, J.F. (1999) Correlations of plasma growth hormone with somatostatin, gonadal steroid hormones and thyroid hormones in rainbow trout during sexual recrudescence. Comparative Biochemistry and Physiology Part B: Biochemistry and Molecular Biology, 123, 251260. doi:10.1016/S0305-0491(99)00059-0

[8] Shimizu, A. (2003) Effect of photoperiod and temperature on gonadal activity and plasma steroid levels in a reared strain of the mummichog (Fundulus heteroclitus) during different phases of its annual reproductive cycle. General and Comparative Endocrinology, 131, 310-324. doi:10.1016/S0016-6480(03)00026-1

[9] Hellqvist, A., Bornestaf, C., Borg, B. and Schmitz, M. (2004) Cloning and sequencing of the FSH-b and LH-b subunit in the three-spined stickleback, Gasterosteus aculeatus, and effects of photoperiod and temperature on LH-b and FSH-b mRNA expression. General and Comperative Endocrinolology, 135, 167-174.

[10] Soria, F.N., Strussmann, C.C.A. and Miranda, L.A. (2008) High water temperatures impair the reproductive ability of the pejerrey fish Odontesthes bonariensis: Effects on the hypophyseal-gonadal axis. Physiological and Biochemical Zoology, 81, 898-905. doi:10.1086/588178

[11] Sumpter, J.P. (1997) Environmental control of fish reproduction: A different perspective. Fish Physiology and Biochemistry, 17, 25-31. doi:10.1023/A:1007782305962

[12] Seale, A.P., Riley, L.G., Leedom, T.A., Kajimura, S., Dores, R.M., Hirano, T. and Grau, E.G. (2002) Effects of environmental osmolality on release of prolactin, growth hor-mone and ACTH from the tilapia pituitary. General and Comparative Endocrinology, 128, 91-101. doi:10.1016/S0016-6480(02)00027-8

[13] Breves, J.P., Fox, B.K., Pierce, A.L., Hirano, T. and Grau, E.G. (2010) Gene expression of growth hormone family and glucocorticoid receptors, osmosensors, and ion transporters in the gill during seawater acclimation of Mozambique tilapia, Oreochromis mossambicus. Journal of Experimental Zoology Part A: Ecological Genetics and Physiology, 313, 432-441. doi:10.1002/jez.613

[14] Fox, B.K., Breves, J.P., Davis, L.K., Pierce, A.L., Hirano, T. and Grau, E.G. (2010) Tissue-specific regulation of the growth hormone/insulin-like growth factor axis during fasting and refeeding: Importance of muscle expression of IGF-I and IGF-II mRNA in the tilapia. General and Comperative Endocrinology, 166, 573-580. doi:10.1016/j.ygcen.2009.11.012

[15] Degani, G. (2001) Blue gourami (Trichogaster trichopterus) model for labyrinth fish. Laser Pages Publishing, Israel, 134.

[16] Cole, B., Tamura, C.S. and Baile, R. (1999) A manual for commercial production a temporal period spawner. Center of Tropical and Subtropical Aquaculture Publication, 135, 1-32.

[17] Priest, A. (2002) When two ar three and gold is blue. Osphronemid, 4, 6-11.

[18] Jackson, K., Abraham, M. and Degani, G. (1994) Oocyte maturation triggered by the presence of male in the blue gourami (Trichogaster trichopterus). Journal of Morphology, 220, 1-9. doi:10.1002/jmor.1052200102

[19] Degani, G. (1993) The effect of sexual behavior on oocyte development and steroid changes in Trichogaster trichopterus. Copeia, 4, 1091-1196. doi:10.2307/1447089

[20] Degani, G. (1993) Reproduction control in multi-spawning asynchronic Trichogaster trichopterus (Pallas) as a model for the Anabantidae family. Trends in Comparative Biochemistry and Physiology, 1269-1275.

[21] Degani, G., Jackson, K. Goldberg, D., Sarfati, R. and Avtalion, R.R. (2003) betaFSH, betaLH and growth hormone gene expression in blue gourami (Trichogaster trichopterus, Pallas 1770) during spermatogenesis and male sexual behavior. Zoological Science, 20, 737-743. doi:10.2108/zsj.20.737

[22] Degani, G., Yom-Din, S., Goldberg, D. and Jackson, K. (2010) cDNA cloning of blue gourami (Trichogaster trichopterus) prolactin and its expression during the gonadal cycles of males and females. Journal of Endocrinological Investigation, 33, 7-12.

[23] Goldberg, D., Jackson, K., Yom-Din, S. and Degani, G. (2004) Growth hormone of Trichogaster trichopterus: cDNA cloning, sequencing and analysis of mRNA expression during oogenesis. Journal of Aquaculture in the Tropics, 19, 215-229.

[24] Degani, G. and Boker, R. (1992) Sensitivity to maturation-inducing steroids and gonadotropin in the oocytes of blue gourami Trichogaster trichopterus (Anabantidae, Pallas, 1770). General and Comparative Endocrinology, 85, 430-439. doi:10.1016/0016-6480(92)90088-2

[25] Degani, G., Jackson, K., Yom-Din, S. and Goldberg, D. (2006) cDNA cloning and mRNA expression of growth hormone in belontiidae (Anabantoidei suborder) Isr. Journal of Aquaculture, 58, 124-136.

[26] Levy, G. and Degani, G. (2012) Involvement of GnRH, PACAP and PRP in the reproduction of blue gourami females (Trichogaster trichopterus). Journal of Molecular Neuroscience, 48, 603-616. doi:10.1007/s12031-012-9730-8

[27] Degani, G., Mananos, E.L., Jackson, K., Abraham, M. and Zohar, Y. (1997) Changes in plasma and pituitary in female blue gourami during the end of vitellogenesis and 
final oocyte maturation. Journal of Experimental Zoology, 279, 377-385. doi:10.1002/(SICI)1097-010X(19971101)279:4<377::AI D-JEZ7>3.0.CO;2-L

[28] Levy, G., Gothilf, Y. and Degani, G. (2009) Brain gonadotropin releasing hormone 3 expression variation during oogenesis and sexual behavior and its effect on pituitary hormonal expression in the blue gourami. Comparative Biochemistry and Physiology Part A: Molecular \& Integrative Physiology, 154, 241-248. doi:10.1016/j.cbpa.2009.06.010

[29] Levy, G., Jackson, K. and Degani, G. (2010) Association between pituitary adenylate cyclase-activating polypeptide and reproduction in the blue gourami. General and Comparative Endocrinology, 166, 83-93. doi:10.1016/j.ygcen.2009.09.015

[30] Levy, G. and Degani, G. (2011) Evidence of a reproduction-related function for pituitary adenylate cyclase-activating polypeptide-related peptide in an Anabantidae fish. Journal of Molecular Endocrinology, 46, 101-110. doi:10.1530/JME-10-0065

[31] Jackson, K., Goldberg, D., Ofir, M., Abraham, M. and Degani, G. (1999) Blue gourami (Trichogaster trichopterus) gonadotropic beta subunits (I and II) cDNA sequences and expression during oogenesis. Journal of Molecular Endocrinology, 23, 177-187. doi:10.1677/jme.0.0230177

[32] Degani, G., Jackson, K., Goldberg, D., Sarfati, R. and Avtalion, R.R. (2003) betaFSH, betaLH and growth hormone gene expression in blue gourami (Trichogaster trichopterus, Pallas 1770) during spermatogenesis and male sexual behavior. Zoological Science, 20, 737-743. doi:10.2108/zsj.20.737

[33] Pfaffl, M.W. (2001) A new mathematical model for relative quantification in real-time RT-PCR. Nucleic Acids Research, 29, e45. doi:10.1093/nar/29.9.e45

[34] Muller, P.Y., Janovjak, H., Miserez, A.R. and Dobbie, Z. (2002) Processing of gene expres-sion data generated by quantitative real-time RT-PCR. Biotechniques, 32, 13721379.

[35] Brauner, C.J. Suvajdzic, K. Nilsson, G. and David, R. (2007) Fish physiology, toxicology, and water quality. Proceedings of the 9th International Symposium, Ecosystems Research Division, Capri.

[36] Onuma, T.A., Ban, M., Makino, K., Katsumata, H., Hu, W., Ando, H., Fukuwaka, M.A., Azumaya, T. and Urano, A. (2010) Changes in gene expression for $\mathrm{GH} / \mathrm{PRL} / \mathrm{SL}$ family hormones in the pituitaries of homing chum sal- mon during ocean migration through upstream migration. General and Comperative Endocrinology, 166, 537-548. doi:10.1016/j.ygcen.2010.01.015

[37] Manzon, L.A. (2002) The role of prolactin in fish osmoregulation: A review. General and Comparative Endocrinology, 125, 291-310. doi:10.1006/gcen.2001.7746

[38] Hirano, T., Ogasawara, T. Hasegawa, S., Iwata, M. and Nagahama, Y. (1990) Changes in plasma hormone levels during loss of hypoosmoregulatory capacity in mature chum salmon (Oncorhynchus keta) kept in seawater. General and Comperative Endocrinology, 78, 254-262. doi:10.1016/0016-6480(90)90012-B

[39] Onuma, T., Kitahashi, T., Taniyama, S., Saito, D., Ando, H. and Urano, A. (2003) Changes in expression of genes encoding gonadotropin subunits and growth hormone/ prolactin/somatolactin family hormones during final maturation and freshwater adaptation in prespawning chum salmon. Endocrine, 20, 23-34. doi:10.1385/ENDO:20:1-2:23

[40] Degani, G. and Gallagher, M.L. (1995) Growth and nutrition of Eels. Laser Pages Publishing, Israel, 174

[41] Nagahama, Y. (1994) Endocrine regulation of gametogenesis in fish. International Journal of Developmental Biology, 38, 217-229.

[42] Levy, G. and Degani, D. (non-published data) Two $\mathrm{GnRH}$ variants in the blue gourami: Gene expression during reproductive cycle and effect on pituitary hormones.

[43] Weber, G.M., Powell, J.F., Park, M., Fischer, W.H., Craig, A.G., Rivier, J.E., Nanakorn, U., Parhar, I.S., Ngamvongchon, S., Grau, E.G. and Sherwood, N.M. (1997) Evidence that gonadotropin-releasing hormone $(\mathrm{GnRH})$ functions as a prolactin-releasing factor in a teleost fish (Oreochromis mossambicus) and primary structures for three native GnRH molecules. Journal of Endocrinology, 155, 121-132. doi:10.1677/joe.0.1550121

[44] Ogawa, S., Akiyama, G., Kato, S., Soga, T., Sakuma, Y. and Parhar, I.S. (2006) Immunoneutralization of gonadotropin-releasing hormone type-III suppresses male reproductive behavior of cichlids. Neuroscience Letters, 403, 201-205. doi:10.1016/j.neulet.2006.02.041

[45] Yamamoto, N., Oka, Y. and Kawashima, S. (1997) Lesions of gonadotropin-releasing hor-mone-immunoreactive terminal nerve cells: Effects on the reproductive behavior of male dwarf gouramis. Neuroendocrinology, 65, 403-412. doi:10.1159/000127203

[46] Mank, J., Promislow, D. and Avise, J. (2005) Phylogenetic perspectives in the evolution of parental care in rayfinned fishes. Evolution, 59, 1570-1578. 